\title{
Antibacterial activity of endophytic fungi from some medicinal plants of Biligirirangana hill, India
}

\begin{abstract}
K.S. Sushma*
Department of Studies and Research in Microbiology, Mangalore University, Post Graduate Centre, Jnana Kaveri Campus Kodagu-571232 (Karnataka), India

M. Jayashankar

Department of Studies and Research in Microbiology, Mangalore University, Post Graduate Centre, Jnana Kaveri Campus Kodagu-571232 (Karnataka), India

Mohammed Ali Saeed

Department of Studies and Research in Microbiology, Mangalore University, Post Graduate Centre, Jnana Kaveri Campus Kodagu-571232 (Karnataka), India

A.K. Vinu

Department of Studies and Research in Microbiology, Mangalore University, Post Graduate Centre, Jnana Kaveri Campus Kodagu-571232 (Karnataka), India

*Corresponding author. E-mail: ksushmitha80@gmail.com

Abstract

Twenty fungal endophytes were isolated from different medicinal plants of Biligirirangana Hill, Chamarajanagar dist. Phytochemical analysis of ethyl acetate extract showed positive results for tanins, flavonoids, steroids, terpenoids, glycosides, saponins and alkaloids except saponin and flavonoid tests. The crude extracts of the fungal endophytes were tested against two gram positive and two gramnegetive bacteria for its antibacterial activity. The highest zone of inhibition was produced by Fusarium sps (AB9)35mm. All the crude extracts were found to be effective against Escherichia coli, Bacillus subtilis and Staphylococcus aureus rather in Pseudomonas aerogenosa. Among them the highest inhibition zone was produced in Penicillium sp (AB11) $24 \mathrm{~mm}$, Cladosporium sp(AB3) $21 \mathrm{~mm}$, and Aspergillus $s p(A B 12) 30 \mathrm{~mm}$. Therefore, endophytic fungi can be a good source to inhibit the growth of harmful pathogens.
\end{abstract}

Keywords: Antibacterial activity, Crude extracts, Endophytic fungi, Phytochemical analysis

\section{INTRODUCTION}

Plants consists of endophytes which colonize inter or intracellular tissue of the host plant and spend whole or part of its life cycle without causing any apparent symptoms (Tan and Zhou, 2001). Endophyic fungi are the group of unexplored organism of bioactive potential compounds (Palem et al., 2016). All plant species harbor endophytes in order to protect host against pathogens, environmental factors, nutritional status, as well as the developmental stages of the host and endophyte (Schulz and Boyle 2006). Endophytes constitutes large microbial diversity which are the sources of secondary metabolites helps in the production of novel bioactive molecules. After the discovery of (Taxol) paclitaxel an anticancer drug was isolated from Taxomyces adrenae (Stierle et al., 1993). Endophytic fungi exhibit properties such as anticancer, anti-fungal, anti-bacterial (Wiyakrutta et al., 2004) anti-diabetic andimmuno-suppressant compound (Strobel and Daisy, 2003). The endo-

\section{Article Info}

DOI:10.31018/jans.v10i4.1923 Received: October 20, 2018 Revised: November 20, 2018 Accepted: November 28, 2018

\section{How to Cite}

Sushma, K.S. et al. (2018). Antibacterial activity of endophytic fungi from some medicinal plants of Biligirirangana hill, India. Journal of Applied and Natural Science, 10(4): 1286-1290 phytic fungi produce constituents such as alkaloids, steroids, tanins, flavonoids and phenolic compounds (Hill, 1952). The present study investigates the phytochemical analysis and antibacterial activity against human pathogen.

\section{MATERIALS AND METHODS}

Collection of samples: Medicinal plants (Table 1) were collected from BR Hills, Chamarajanagar district, hill range situated in south eastern part of Karnataka, lies in the coordinates of $77^{\circ}-77^{\circ} 16^{\prime} \mathrm{E}$, $11^{\circ} 47^{\prime}-12^{\circ} 9^{\prime} \mathrm{N}$, covering an area of $540 \mathrm{sq} \mathrm{km}$ (Madegowda 2009). Plants were identified based on morphological characteristics (Bremer et al., 1998). Fresh healthy plants samples were collected in sterile polythene bags and brought to the laboratory within 24 hrs.

Isolation of endophytic fungi: The collected plants samples were surface sterilizedwith some modification (Barmet, 1992). Plant material was first washed under running tap water to remove 
dirt, washed with distilled water then sequentially rinsing the plant material with $70 \%$ ethanol for 30 sec followed by $0.5 \%$ sodium hypochloritefor $2-3$ min, and rinse with $70 \%$ ethanol for $2 \mathrm{~min}$, and finally with distilled water. The plant materials were cut into small segments aseptically and dried using sterile filter papers. The dried segments were placed in petri dishes containing Sabaraud dextrose agar (SDA) media and incubated at $27^{\circ} \mathrm{C}$ for 4-6 days. After incubation period, the visual growth for each fungus was observed. Each colony of the fungal isolates were then transferred separately to obtain pure culture and maintained at $4^{\circ} \mathrm{C}$ for further use.

Identification of endophytic fungi: The morphological study of fungal colony were observed bygrowing the fungi on SDA media and incubating for 7 days and was noted by observing back and front views of the plates macroscopically (Barnett and Hunter, 1972). The unknown fungal colony was identified microscopically by studying their cultural characteristics, mycelium andspore formation. Slides were prepared by wet mount method using lacto phenol cotton blue stain and observed under binocular microscope at 40x and 100x magnifications (Schulz et al, 1993).

Preparation of crude extracts: Preparation of crude extracts was followed by the procedure of Subramanian (1983). Theisolates of endophytic fungi were inoculated into $250 \mathrm{ml}$ Erlenmeyer flasks containing $100 \mathrm{~mL}$ sabaruads dextrose broth and incubated at room temperature for 21 days ina rotary shaker. After incubation, the broth culture was filtered to separate mycelia and the filtrate. To the filtrate equal volume of ethyl acetate was added, mixed well for 10 minutes and kept till the two clear immiscible layers were formed. The upper layer of ethyl acetate containing the extracted compounds was separated using separating funnel. The mycelium was grinded in pestle and mortar using ethyl acetate as solvent and filtered using cheese cloth. Both mycelia and culture filtrate extracts were pooled together and evaporated to dryness in hot air oven of $100^{\circ} \mathrm{C}$ and stored at $4^{\circ} \mathrm{C}$ to be used for further analysis.

Tests against human pathogens: The antibacterial potentiality of the isolated endophytic fungi was tested against four human pathogenic bacteria two Gram positive Bacillus subtilis and Staphylococcus aureus and two Gram negative bacteria Escherichia coli and Pseudomonas aerogenosa collected from Microbial Type Culture Collection (MTCC), Chandigarh and maintained in our laboratory.

Agar well diffusion method: Agar well diffusion test was performed according to(Lin et al, 2002) by using sterilized Mueller Hinton Agar $(\mathrm{pH} 7.3 \pm$ 0.1 ). These plates were swabbed by bacterial cultures and wells were prepared with a sterile cork borer of diameter $6 \mathrm{~mm}$ in a distance of $15 \mathrm{~mm}$ from each well. Different concentrations $(30 \mu \mathrm{l}$, $50 \mu \mathrm{l}$ and $100 \mu \mathrm{l})$ of the fungal extracts were dispensed aseptically included with their respective controls using a micropipette and incubated at $37^{\circ}$ $C$ for 24 hours. The diameters of the zone of inhibition (ZOI) were measured with a ruler $(\mathrm{mm})$.

Phytochemical property: The endophytic fungal crude extracts were subjected to qualitative chemical tests to determine phytochemical constituents carried out on the aqueous extract using standard procedures to identify compounds (Collee et al, 1996), (Harborne, 1973), (Bandoni et al, 1976).

Tanins: About $1 \mathrm{ml}$ of the samplewas taken and few drops of $0.1 \%$ ferric chloride was added and observed for brownish green or a blue-black coloration.

Flavornoids: $5 \mathrm{ml}$ of dilute ammonia solution were added to a portion of the aqueous filtrate of each plant extract followed by addition of concentrated $\mathrm{H}_{2} \mathrm{SO}_{4}$. A yellow coloration observed in each extract indicated the presence of flavonoids. Steriods: Two ml of acetic anhydride was added to $1 \mathrm{ml}$ of sample with $2 \mathrm{mlH}_{2} \mathrm{SO}_{4}$. The colour changed from violet to blue or green in samples indicating the presence of steroids.

Terpenoids: Five $\mathrm{ml}$ of each extract was mixed in $2 \mathrm{ml}$ of chloroform, and $3 \mathrm{ml}$ of concentrated $\mathrm{H}_{2} \mathrm{SO}_{4}$ was carefully added to form a layer. A reddish brown coloration of the inter face was formed to show positive results for the presence of terpenoids.

Glycosides: Five $\mathrm{ml}$ of each extracts was treated with $2 \mathrm{ml}$ of glacial acetic acid containing one drop of ferric chloride solution. This wasunderlayed with $1 \mathrm{ml}$ of concentrated sulphuric acid. A violet ring may appear below the brown ring indicates positive result.

Saponin: $2 \mathrm{ml}$ of sample was mixed with $3 \mathrm{ml}$ of distilled water and shaken vigorously for a stable persistent froth. The frothing was mixed with 3 drops of olive oil and shaken vigorously, then observed for the formation of emulsion.

Alkaloids: To the sample a drop of iodine was added, the appearance of reddish brown indicates positive result for alkaloids.

\section{RESULTS AND DISCUSSION}

The ethyl acetate crude extract of isolated fungal endophytes from the few selected medicinal plants tested against two gram positive and two gram negative pathogenic bacteria for antibacterial activity are given in Table 1 while the zone of inhibitions measured in mmare mentioned in Table 2. All the crude extracts were found to be effective against Escherichia coli, Bacillus subtilis and Staphylococcus aureus and not in Pseudomonas aerogenosa. Among them Penicillium sp, Cladosporium sp, Aspergillus sp. and Fusarium sp.showed the highest zone of inhibition of 24 $\mathrm{mm}, 21 \mathrm{~mm} 30 \mathrm{~mm}$ and $35 \mathrm{~mm}$. AB12 isolate 
Sushma, K.S. et al. / J. Appl. \& Nat. Sci. 10 (4): 1286-1290 (2018)

Table 1. List of endophytic fungi isolated and identified from few selected medicinal plants collected from BR Hills.

\begin{tabular}{|c|c|c|c|}
\hline SI. No. & Code no. & Identified isolates & Isolated from medicinal plant \\
\hline 1. & $\mathrm{AB} 1$ & Cladosporium sp & Tylophoraindica \\
\hline 2. & AB2 & Fusarium oxysporum & Eucalyptus nilgirans \\
\hline 3. & AB3 & Cladosporium cladosporoids & Rauvolfiatetraphyla \\
\hline 4. & AB4 & Alternaria alternate & Citrus sinensis \\
\hline 5. & AB5 & Colletotricum sp. & Tylophoraindica \\
\hline 6. & AB6 & Gliocladium sp. & Emblica officinalis \\
\hline 7. & $A B 7$ & Penicillium notatum & Gymnemasylvestri \\
\hline 8. & $A B 8$ & Penicillium sp. & Azadirachtaindica \\
\hline 9. & $A B 9$ & Fusarium sp. & Eucalyptus nigirans \\
\hline 10. & AB10 & Alternaria sp. & Murrayakoiengii \\
\hline 11. & AB11 & Penicillium $s p$ & Fever plant \\
\hline 12. & $\mathrm{AB} 12$ & Aspergillus repens & Citrus medica \\
\hline 13. & $\mathrm{AB} 13$ & Phomaherbarum & Cycleapeltata \\
\hline 14. & AB14 & Phyllostictasp & Asclepiascurassavica \\
\hline 15. & AB15 & Penicillumitalicum & Catharanthesrosea \\
\hline 16. & AB16 & Alternaria $s p$ & Eryngium foetidum \\
\hline 17. & $\mathrm{AB} 17$ & Bipolaris maydis & Ocimumtenuliformis \\
\hline 18. & AB18 & Mycelia & Tinosporacordifolia \\
\hline 19. & AB19 & Leptospherulinaarachidicola & Tinosporacordifolia \\
\hline 20. & AB20 & Colletotrichum sp. & Ricinus communis \\
\hline
\end{tabular}

Table 2. Antibacterial activity of the endophytic fungal isolates against four human pathogens.

\begin{tabular}{|c|c|c|c|c|c|}
\hline \multirow[t]{2}{*}{ SI.No. } & \multirow{2}{*}{$\begin{array}{l}\text { Code no. } \\
\text { of fungal } \\
\text { isolates }\end{array}$} & \multicolumn{4}{|c|}{ Zone of Inhibition measured in (mm) } \\
\hline & & Escherichia coli & $\begin{array}{l}\text { Bacillus } \\
\text { subtilis }\end{array}$ & $\begin{array}{l}\text { Staphylococcus } \\
\text { aureus }\end{array}$ & $\begin{array}{l}\text { Pseudomonas aer- } \\
\text { ogenosa }\end{array}$ \\
\hline 1. & $\mathrm{AB} 1$ & 15 & 15 & 20 & - \\
\hline 2. & AB2 & 16 & 14 & 20 & - \\
\hline 3. & AB3 & 30 & 14 & 21 & - \\
\hline 4. & AB4 & 12 & 17 & 18 & - \\
\hline 5. & AB5 & 15 & 15 & 19 & - \\
\hline 6. & AB6 & 15 & 18 & 18 & - \\
\hline 7. & AB7 & 16 & 18 & 17 & - \\
\hline 8. & AB8 & 23 & 24 & 23 & - \\
\hline 9. & AB9 & 17 & 14 & 35 & - \\
\hline 10. & AB10 & 12 & 16 & 17 & - \\
\hline 11. & AB11 & 24 & 22 & 22 & 12 \\
\hline 12. & $\mathrm{AB} 12$ & 30 & 30 & 30 & 25 \\
\hline 13. & AB13 & 22 & 22 & 21 & - \\
\hline 14. & AB14 & - & 20 & 23 & - \\
\hline 15. & AB15 & 16 & 16 & 10 & - \\
\hline 16. & AB16 & 16 & 16 & 14 & - \\
\hline 17. & AB17 & 18 & 22 & 17 & - \\
\hline 18. & AB18 & 16 & 24 & 15 & - \\
\hline 19. & AB19 & 30 & 30 & - & - \\
\hline 20. & AB20 & - & - & 30 & - \\
\hline
\end{tabular}

could inhibit all these four bacteria. $50 \mu \mathrm{l}$ and $100 \mu \mathrm{l}$ of the extracts produced maximum zone of inhibition in Gram positive bacteria $S$. aureus $(30 \mathrm{~mm})$ and $B$. subtilis $(30 \mathrm{~mm})$ and Gram-negative bacteria $P$. aerogenosa $(25 \mathrm{~mm})$ and $E$. coli $(30 \mathrm{~mm})$ which showed antibacterial activity. $A B 8$ isolate showed inhibition zone in $S$. aureus $(23 \mathrm{~mm}), B$. subtilis $(24 \mathrm{~mm})$, E. coli $(23 \mathrm{~mm})$ and no zone was formed in $P$. aerogenosa. AB10 isolate formed the minimum zone of inhibition (Table 2). The antibacterial activity of fungal samples resistant to pathogenic bacteria further screened for phytochemical constituents'analysis of the crude extracts for the presence of tanins, flavonoids, steroids, terpe- noids, glycosides, saponins and alkaloids showed positive results except for saponin and flavonoid tests (Table 3).

Antibacterial activities for endophytic fungi were found to be effective against Gram positive bacteria $S$. aureus, $B$. subtilis and Gram-negative bacteria $P$. aerogenosa, $E$. coli. The result showed that fungal crude ethyl acetate extract inhibited grampositive than gram-negative bacteria. The endophyte could inhibit the growth of Gram positive bacteria Staphylococcus aureus and Bacillus subtilis to a greater degree than Gram negative bacteria Escherichia coli (Chareprasert et al, 2006). The antimicrobial activity of the fungal isolates have 
Table 3. Phytochemical analysis of the fungal crude extracts for the presence of compounds.

\begin{tabular}{|c|c|c|c|c|c|c|c|}
\hline Sample & Tanin & Flavanoid & Steroid & Terpenoid & Glycosides & Saponin & Alkaloid \\
\hline $\mathrm{AB} 1$ & + & - & + & + & - & - & + \\
\hline AB2 & + & - & + & + & + & - & + \\
\hline AB3 & + & - & + & + & + & - & + \\
\hline AB4 & + & - & - & - & + & - & + \\
\hline AB5 & + & - & + & - & - & - & + \\
\hline AB6 & + & - & - & + & - & - & - \\
\hline$A B 7$ & + & - & + & + & + & - & + \\
\hline AB8 & + & - & + & + & + & - & + \\
\hline AB9 & - & - & - & + & - & - & + \\
\hline AB10 & - & - & - & - & - & - & - \\
\hline AB11 & + & - & + & + & + & - & + \\
\hline AB12 & + & - & + & + & + & - & + \\
\hline AB13 & + & - & + & + & + & - & + \\
\hline AB14 & - & - & - & + & - & - & + \\
\hline AB15 & - & - & + & + & - & - & - \\
\hline AB16 & - & - & - & + & + & - & + \\
\hline $\mathrm{AB} 17$ & + & - & - & - & + & - & + \\
\hline AB18 & + & - & - & + & - & - & + \\
\hline AB19 & - & - & + & - & - & - & + \\
\hline AB20 & + & - & + & + & - & - & + \\
\hline
\end{tabular}

+ Present, - Absent

shown good inhibition Gliocladium sp (80\%) followed by Penicillium adametzi(73.3\%) and $P$. chrysogenum (71.1\%) (Vinu and Jayashankara, 2011). Antibacterial activity of endophytic fungi was observed against selected test organisms. The number of extracts of sea grasses Cymodoceaserrulata, Halophila ovalis and Zosteracapensis indicated that sea grasses are good source of antimicrobial-producing endophytic fungiwith some extracts also possess antibacterial activity(Kumar et al, 2008).

The active metabolites contain chemical groups such as phenols, steroids, flavonoids, quinines, terpenoids, xantones, peptides, cytocatalasins, alkaloids, aliphatic compounds, and phenyl propanoids (Ladoh-Yemed et al., 2015) In the current study, phytochemical analysis of ethyl acetate extracts of most endophtic fungi extract showed the presence of alkaloids, steroids, tannin and glycoside. A study for (Ramesha and Srinivas, 2014) revealed the presence of alkaloids, flavonoids, steroids, phenol and phenolic compounds in crude extracts of endophytic fungi isolated from Plumeria acuminata L. and Plumeria obtusifolia L. Our results are in accordance with previous reports wherein the endophytes have shown the presence of different phytochemicals have antimicrobial activities. In addition, the use of endophytes as potential factories for the production of secondary metabolites might revolutionize agricultural, pharmaceutical and biotechnological research in the near future (Suresh et al., 2013)

\section{Conclusion}

The present study represents the antibacterial activity of endophytic fungi isolated from medicinal plants, most of isolates had inhibited active ranged between $12-30 \mathrm{~mm}$ against tested strains. Compounds from tested plants can be exploited to commercial values provided in vivo assessment of the compounds is studied in future and could be a potential source of bioactive compounds to explore for the development of new drugs for human diseases and phytopathogens.

\section{ACKNOWLEDGEMENTS}

The authors are thankful to Mangalore University for providing the fellowships and all the facilities required to carry out this work.

\section{REFERENCES}

1. Bandoni, AL., Mendiondo, ME., Rondina, RVD. and Coussio, JD (1976). Survey of Argentine medicinal plants, folklore and phytochemical screening II. Econ. Bot., 30: 161-185.

2. Barmet, H., (1992). The natural pharmacy: An encyclopedic illustrated guide to medicine from nature. Mirriampolunin and Christopher Robins, Great Britain.

3. Barnett and Hunter. L.,(1972). Illustrated genera of imperfect fungi (3rd Ed). Burgess Publishing Company, California.

4. Bremer, K., Chase, MW., Stevens, PF., (1998). An ordinal classification for the families of flowering plants. Annals of the Missouri Botanical Garden; 85: 531-553.

5. Chareprasert, S., Piapukiew, J., Thienhirun, S., Whalley, A. and Sihanonth, P (2006). Endophytic fungi of teak leaves Tectonagrandis $L$. and rain tree SamaneasamanMerr. World Journal of Microbiology and Biotechnology, 22: 481-486.

6. Collee, JG., Marmion, BP., Fraser, AG., Simmons (1996). A. Mackie and McCartney Practical Medical Microbiology. 14th ed. Churchill-Livingstone.

7. Harborne, JB., (1973). Phytochemical methods, London. Chapman and Hall, Ltd. pp. 49-188.

8. Hill, AF., (1952). Economic Botany. A textbook of 
useful plants and plant products. 2nd edn. McGarwHill Book Company Inc, New York.

9. Kumar, CS., Sarada, DVL, Gideon, TP., Rengasamy, R. (2008). Antibacterial activity of three South Indian seagrasses, Cymodoceaserrulata, Halophila ovalis and Zosteracapensis. World J Microbiol Biotechnol24: 1989-1992. Doi: 10.1007/s11274-008-9695-5.

10.Ladoh-Yemeda, CF., Nyegue. MA., Ngene, JP., Benelesse, GE., Lenta B., Wansi, JD., Mpondo Mpondo, E., Dibong, SD (2015). Identification and phytochemical screening of Endophytic fungi from stems of Phragmanthera capitata (Sprengel) S. Balle (Loranthaceae). Journal of Applied Biosciences 90:8355-8360.

11.Lin, Y., Wang, J., Wu, X., Zhou, S., Vrijmoed, LL, and Jones, EG. (2002). A novel compound enniatin $G$ from the mangrove fungus Halosarpheia $s p$. (strain\# 732) from the South China Sea. Aust $J$ Chem; 55(3):225-7.

12.Madegowda, C.,(2009). Traditional knowledge and conservation. Econ Polit Wkly; 44:65-9.

13.Palem, PPC., Kuriakose, GC., Jayffabaskaran, C., (2016) Correction: An Endophytic Fungus, Talaromycesradicus, Isolated from Catharanthus roseus, Produces Vincristine and Vinblastine, Which Induce Apoptotic Cell Death. PLOS ONE 11(4): e0153111.

14.Ramesha, A. and Srinivas, C.(2014). Antimicrobial activity and phytochemical analysis of crude extractsof endophytic fungi isolated from Plumeria acuminata L. and Plumeria obtusifolia L. European Journal of Experimental Biology, 4(2):35-43.

15.Schulz, B., and Boyle, C. (2006). What are endophytes? In: Schulz B, Boyle C, Sieber T, editors.Microbial root endophytes. Berlin: SpringerVerlag; p. 1-13.
16.Schulz, B., Wanke, U., Draeger, S., and Aust, HJ (1993). Endophytic from herbaceous plants and shrubs: Effectiveness of surface sterilization method. Mycol Res; 97:1447-50.

17.Stierle, A., Strobel, G., Stierle, D (1993). Taxol and taxane production by Taxomycesandreanae, an endophytic fungus of Pacific yew. Science, 260:214-216

18.Strobel, G. and Daisy, B. (2003). Bioprospecting for Microbial Endophytes and Their Natural Products.Microbiology and MolecularBiologyReviews 67 (4):491-502.

19.Subramanian, CV. (1983). Hyphomycetes. Taxonomy and Biology. Academic press. London Vol. I and II. 1-930.

20.Suresh, B. D., Vijaya T., Venkateswarulu, N., Chandramouli, K., Krishnakanth, S., Chamarthi, N. (2013). Endophytic fungal diversity from endemic plants of Tirumala hills in Eastern ghats and their anti-candidal activity. World Journal of Pharmaceutical Research, 3 (1): 834-847.

21.Tan, RX, and Zhou, WX (2001). Endophytes: A rich source of functional metabolites. Nat. Prod. Rep, 18, 448-459.

22.Vinu, AK and Jayashankara, M. (2011). Potentiality of Endophytic Fungi of Justicia wayanadensis as Bioagent against Rhizoctoniasolani. Asian Journal of Microbiology, Biotechnology \& Environmental Sciences Pape,13 (1) 7-9.

23.Wiyakrutta, S., Sriubolmas, N., Phanput, W., Thongon, N., Danwisetkanjana, K., Ruangrungsi, N. (2004). Endophytic fungi with anti-microbial, anticancer, and anti-malarial activities isolated from Thai medicinal plants. World Journal of Microbiology and Biotechnology, 20:265-272 